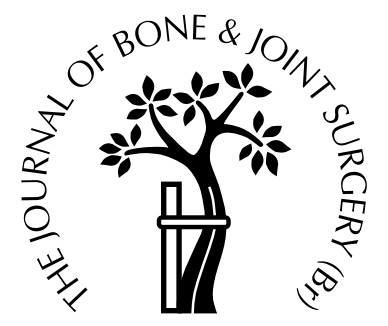

\title{
Positive effects of anabolic steroids, vitamin D and calcium on muscle mass, bone mineral density and clinical function after a hip fracture
}

\author{
A RANDOMISED STUDY OF 63 WOMEN \\ M. Hedström, K. Sjöberg, E. Brosjö, K. Åström, H. Sjöberg, N. Dalén \\ From the Karolinska Institute and Danderyd Hospital, Sweden
}

\begin{abstract}
A total of 63 women who had an operation for a fracture of the hip was randomly allocated to one year of treatment either with anabolic steroids, vitamin D and calcium (anabolic group) or with calcium only (control group). The thigh muscle volume was measured by quantitative CT. The bone mineral density of the hip, femur and tibia was assessed by quantitative CT and dual-energy x-ray absorptiometry and of the heel by quantitative ultrasound.

Quantitative CT showed that the anabolic group did not lose muscle volume during the first 12 months whereas the control group did $(p<0.01)$. There was less bone loss in the proximal tibia in the anabolic group than in the control group. The speed of gait and the Harris hip score were significantly better in the anabolic group after six and 12 months.

Anabolic steroids, even in this moderate dose, given in combination with vitamin $D$ and calcium had a beneficial effect on muscle volume, bone mineral density and clinical function in this group of elderly women.

J Bone Joint Surg [Br] 2002;84-B:497-503.

Received 14 May 2001; Accepted after revision 21 August 2001
\end{abstract}

Functional recovery after fracture of the hip is often incomplete. A catabolic state develops after operation ${ }^{1}$ and malnutrition, which is either present or develops after surgery, ${ }^{2-5}$ contributes to a poor outcome. Many patients cannot return to normal life 6,7 and the mortality rate is high. ${ }^{6,8,9}$ Patients who sustain fractures of the hip lose body-weight and lean body mass after operation. ${ }^{1,10}$ Mus-

M. Hedström, MD, Consultant Orthopaedic Surgeon

K. Åström, MD, Orthopaedic Surgeon

H. Sjöberg, MD, PhD

N. Dalén, MD, PhD, Professor

Department of Orthopaedics

K. Sjöberg, MD, Consultant in Geriatrics

Danderyd Geriatric Clinic NLPO

E. Brosjö, MD, Consultant Radiologist

Division of Radiology

Karolinska Institute, Danderyd Hospital, 18288 Danderyd, Sweden.

Correspondence should be sent to Dr M. Hedström.

(C)2002 British Editorial Society of Bone and Joint Surgery 0301-620X/02/412434\$2.00 cle weakness and the associated loss of mobility increase the risk of falls, ${ }^{11}$ further fractures ${ }^{12}$ and functional dependency. ${ }^{13}$ A decrease in lean body mass and protein deficiency leads to generalised weakness, an impaired immune response and slower wound healing. ${ }^{14,15}$ The effect of a small dose of anabolic steroids in these patients has not been evaluated although it has been shown to restore bodyweight in other catabolic states such as acquired immune deficiency syndrome and chronic obstructive pulmonary disease. $^{16,17}$

Both muscles and protein are lost and there is a decrease in bone mineral density (BMD) after fracture of the hip. 18 This decrease is most pronounced in the trabecular bone in the ipsilateral leg, ${ }^{19}$ but is also present in the contralateral hip. ${ }^{18}$ A low BMD is associated with an increased risk of fracture. ${ }^{20}$ The role of synthetic anabolic steroids in the treatment of postmenopausal and post-traumatic osteoporosis is uncertain. Earlier studies on elderly women with osteoporosis have shown positive effects of treatment with nandrolone decanoate on the BMD in the distal forearm and proximal femur. ${ }^{21,22}$

Women show an age-related decline in endogenous androgens which persists into advanced age. ${ }^{23,24}$ It has been suggested that a decline of free testosterone may influence the development of osteoporosis in women. ${ }^{25} \mathrm{~A}$ recent pilot study has suggested that dihydroepiandrosterone, a precursor of both oestrogens and androgens, has a positive effect on both BMD and lean body mass in the elderly. ${ }^{26}$ Elderly women are also prone to deficiency of vitamin $D$ because of reduced exposure to sunlight, decreased synthesis of vitamin D in the skin, low vitamin D in the diet and a decline of the renal synthesis of metabolites of vitamin D. ${ }^{27-31}$ Low serum levels of vitamin D may lead to secondary hyperparathyroidism and bone loss and have been demonstrated in patients with fractures of the hip. $^{32-35}$ Recent data have also shown an increased prevalence of secondary hyperparathyroidism in these patients. $^{34,35}$

The loss of BMD and lean body mass may be modified by treatment with anabolic drugs. We have investigated whether an anabolic steroid given with vitamin D and calcium could reduce postoperative catabolism and give a better outcome after a fracture of the hip without serious adverse effects. 


\section{Patients and Methods}

Between January 1994 and February 1998 we studied 63 women over 65 years of age, who were living independently in their own homes. Those who had been treated with bone-active drugs during the previous years, had a metabolic disease which could influence bone density or were smokers were excluded, as were those who had previously sustained a fracture of the contralateral hip or had cerebrovascular disease affecting mobility. Patients were also excluded if they had significant liver disease, renal calculi, hypercalcaemia, a renal impairment with a serum creatinine $>150 \mathrm{mmol} / 1 \mathrm{dm}^{3}$, uncontrolled hypertension, heart failure, abnormal thyroid function, alcohol abuse or dementia. The study was approved by the Committee for Medical Ethics of Karolinska Hospital.

Patients with subcapital fractures (35) underwent fixation with two parallel screws and those with pertrochanteric fractures (28) with a sliding nail-plate. Four patients died during the year of treatment, two from each group. Two patients were subsequently excluded because of poor health. Four did not wish to participate after surgery, two from each group.

The patients who discontinued treatment were analysed by intention to treat, except for two who were followed for seven and eight months. One developed progressive cholangitis and the other a primary hyperparathyroidism. Seven patients, four from the anabolic group and three from the control group, developed pseudarthrosis or avascular necrosis, and underwent arthroplasty. All were followed for one year with appropriate measurements, but were not included in the assessment of clinical function.

The patients were allocated by sealed envelopes to receive either treatment for one year with nandrolone decanoate $(25 \mathrm{mg}$ intramuscularly every third week), a daily supplement of 1alpha-hydroxylated vitamin D3 (alphacalcidol $0.25 \mu \mathrm{g}$ ) and calcium $(500 \mathrm{mg}$ ), or to receive calcium only.

Of the 63 patients included in the study, 32 were allocated to the anabolic group and 31 to the control group (Table I); 57 patients were followed for six months (30 from the anabolic and 27 from the control group) and 51 for 12 months (25 from the anabolic and 26 from the

Table I. Characteristics of 63 women with a fracture of the hip at the start of the study. Values are given as the mean (SD)

\begin{tabular}{lcc}
\hline Variables & Control group & Anabolic group \\
\hline Number of women & 31 & 32 \\
Age (years) & $81(5.6)$ & $80(6.9)$ \\
Weight $(\mathrm{kg})$ & $61.3(10.5)$ & $60.4(11.5)$ \\
Height $(\mathrm{cm})$ & $161.7(6.9)$ & $161.5(5.7)$ \\
BMI $\left(\mathrm{kg} / \mathrm{m}^{2}\right)$ & $23.3(3)$ & $23.1(4)$ \\
Triceps skinfold $(\mathrm{mm})$ & $15.4(4.7)$ & $14.0(5.3)$ \\
Pertrochanteric fracture & 11 & 17 \\
Femoral neck fracture & 21 & 14 \\
Neck T score & $-2.85(1.0)$ & $-2.58(0.89)$ \\
Neck Z score & $-0.94(0.88)$ & $-0.63(0.78)$ \\
\hline
\end{tabular}

control group). Nandrolone decanoate is a testosterone analogue (estrene derivate) which is thought to have anabolic effects with less masculinising side-effects, such as hoarseness and increased growth of facial hair. It was given in a dose which was half that recommended when the study was instigated in order to minimise side-effects. The intramuscular injections were given by a nurse. A low dose of calcium was chosen for the control group since it has been shown to have a minor effect on BMD when given alone. Alphacalcidol, currently only given to patients with renal failure, was used because renal function is often reduced in the elderly. It was also commonly used for elderly osteoporotic patients when the study was started.

The patients were followed up at three, six, nine and 12 months. Blood and urine samples were obtained at each visit. Bone densitometry and body composition were measured before treatment and after six and 12 months, when assessment also included the Harris hip score ${ }_{37}^{36}$ pain assess-

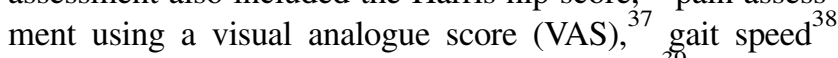
and an activities of daily living (ADL) score. ${ }^{39}$ The ADL index according to Katz et $a^{39}$ is a six-grade scale which reflects bathing, dressing, toilet, transfer, continence and feeding. The Harris hip score includes several parameters with a maximum of 100 points; the absence of pain scores 44 , normal function 47 , absence of deformity 4 and range of movement 5 points. ${ }^{36}$ The VAS is a graphic presentation in which the patient indicates the severity of pain on a line which is $10 \mathrm{~cm}$ long; 0 equals no pain and 10 very severe pain. ${ }^{37}$ The speed of gait was evaluated in a corridor $30 \mathrm{~m}$ long. The patients used their usual walking aids and were instructed to walk at a comfortable speed. ${ }^{38}$

Measurement of BMD and thigh muscle volume. Bone density was measured two to three days after surgery and after six and 12 months. A real BMD, expressed as 'areal density' $\left(\mathrm{g} / \mathrm{cm}^{2}\right)$, of the contralateral hip was determined by dual-energy x-ray absorptiometry (DXA) using DPX-L (Lunar Corporation, Madison, Wisconsin). The results are given for three regions of interest; the neck, Ward's triangle and the trochanteric area. The standard deviation of BMD in patients with hip fracture was compared with the mean level in young adults and age-matched normal subjects, and expressed as the $\mathrm{T}$ and $\mathrm{Z}$ scores, respectively. The precision error of the method was $2 \%$ for measurements of the femoral neck in this group of patients, which is similar to that of previous reports. 40,41

Quantitative CT. We used CT (General Electric Pace Plus, Milwaukee, Wisconsin) for volumetric measurement of the BMD $\left(\mathrm{g} / \mathrm{cm}^{3}\right)$ of the mid-femur, the distal femur and the proximal tibia. The femur was scanned $20 \mathrm{~cm}$ and $5 \mathrm{~cm}$ proximal to the distal limit of the lateral femoral condyle and the tibia $2 \mathrm{~cm}$ below this point. Three circular regions of interest were chosen in the cortical bone in the midfemur. The mean value was estimated as the BMD at this site. By tracing around the distal femur and proximal tibia the bone density and area in that region were determined. The volumes of the thigh muscle were also measured $20 \mathrm{~cm}$ 
Table II. Biochemical serum (S) and urine (U) bone markers on admission and after six and 12 months in the control and anabolic groups. Reference intervals are given by the manufacturer

\begin{tabular}{|c|c|c|c|c|c|c|c|c|c|c|c|}
\hline \multirow[b]{2}{*}{ Marker* } & \multirow[b]{2}{*}{$\begin{array}{l}\text { Reference } \\
\text { intervals }\end{array}$} & \multirow{2}{*}{$\begin{array}{l}\text { Postmenopausal } \\
\text { volunteer group } \\
\text { (range) }\end{array}$} & \multicolumn{2}{|c|}{ On admission } & \multirow{2}{*}{$\begin{array}{l}\text { p value } \\
\text { between } \\
\text { groups }\end{array}$} & \multicolumn{2}{|l|}{6 months } & \multirow{2}{*}{$\begin{array}{l}\text { p value } \\
\text { between } \\
\text { groups }\end{array}$} & \multicolumn{2}{|l|}{12 months } & \multirow{2}{*}{$\begin{array}{l}\text { p value } \\
\text { between } \\
\text { groups }\end{array}$} \\
\hline & & & $\begin{array}{l}\text { Control } \\
\text { group }\end{array}$ & $\begin{array}{l}\text { Anabolic } \\
\text { group }\end{array}$ & & $\begin{array}{l}\text { Control } \\
\text { group }\end{array}$ & $\begin{array}{l}\text { Anabolic } \\
\text { group }\end{array}$ & & $\begin{array}{l}\text { Control } \\
\text { group }\end{array}$ & $\begin{array}{l}\text { Anabolic } \\
\text { group }\end{array}$ & \\
\hline $\begin{array}{l}\text { S-osteocalcin } \\
\left(\mathrm{ng} / \mathrm{cm}^{3}\right)\end{array}$ & 3.7 to 10.0 & 6.3 to 23.3 & $9.2(3.1)$ & $8.7(0.6)$ & 0.7 & $12.2(2.7)$ & $11.7(2.5)$ & 0.5 & $11.55(3.5)$ & $11.44(3.1)$ & 0.9 \\
\hline S-balp (u/l) & 11.6 to 30.6 & 13.7 to 34.3 & $21.6(7.2)$ & $19.25(6.7)$ & 0.2 & $22.9(7.8)$ & $21.2(10.6)$ & 0.5 & $23.4(10.6)$ & $19.6(5.1)$ & 0.1 \\
\hline S-PICP (ng/ml) & 69 to 147 & 90 to 155 & 72.7 (25.7) & $69.7(30.5)$ & 0.7 & $108.9(44.8)$ & $104.7(26.3)$ & 0.7 & $114.9(67.9)$ & $106.3(36.8)$ & 0.6 \\
\hline S-ICTP $(\mu \mathrm{g} / \mathrm{l})$ & 1.8 to 5.0 & 2.8 to 5.6 & $5.43(3.5)$ & $5.03(3.6)$ & 0.7 & $6.55(2.4)$ & $7.7(2.8)$ & 0.1 & $6.9(4.3)$ & $8.5(5.3)$ & 0.3 \\
\hline U-Dpd & 3.0 to 7.4 & 3.4 to 8.1 & $8.0(3.0)$ & $7.6(2.7)$ & 0.7 & $10.5(4.2)$ & $9.1(2.9)$ & 0.2 & $8.9(3.5)$ & $8.1(2.4)$ & 0.4 \\
\hline
\end{tabular}

(nM/mM creatinine)

* S-balp, bone-specific alkaline phosphatase; S-PICP, C-terminal propeptide of type-I collagen; S-ICTP, C-terminal telopeptide of type-I collagen; U-Dpd, deoxypyridinoline

proximal to the distal limit of the lateral condyle. There is a difference in x-ray attenuation between fat, bone and muscle and, by using thresholds for each, the computer calculates the volumes. We calculated the bone mass as the BMD multiplied by the bone volume at each site. In order to elucidate whether the muscle had gained normal muscle tissue or only intracellular fluid, the relative mass of muscle was calculated as the attenuation value multiplied by the volume of the muscle. The CT precision error had earlier been estimated at $2 \%$ for BMD in the mid-femur, $4 \%$ for the distal femur, $5 \%$ for the proximal tibia and $3 \%$ for muscle volume of the mid-femur using the same equipment in our department. ${ }^{42}$ These values were similar to those previously reported. ${ }^{43,44}$

Quantitative ultrasound. For measurements of the heel we used an Achilles ultrasound device (Lunar Corporation, Madison, Wisconsin). The results are expressed as the speed of sound (SOS, $\mathrm{m} / \mathrm{s})$, broad-band US attenuation (BUA, $\mathrm{dB} / \mathrm{mHz}$ ). The stiffness index (\%) is an arbitrary unit expressed by an algorithm of the combination of SOS and BUA $($ BUA-50) $\times 0.67+(\mathrm{SOS}+1380) \times 0.28)$. The precision error of this method has been found to be $2 \%$ to $4 \%$ and is similar to our measurements.

The thickness of the triceps skinfold, reflecting subcutaneous fat mass, ${ }^{46}$ was determined with a calliper before the start of treatment and after six and 12 months. The body mass index (BMI, weight in $\mathrm{kg} /$ height in $\mathrm{m}^{2}$ ) was also calculated. Both routine laboratory tests and measurements of biochemical bone markers were done on admission, and after six and 12 months (Table II). Markers were measured with ELISA and RIA kits according to the manufacturers' instructions (Novatek Healthcare AB, Södertälje, Sweden; Orion Diagnostics, Espoo, Finland).
Statistical analysis. Student's $t$-test was used for parametric independent groups, and for non-parametric tests the Wilcoxon rank-sum test was used to compare groups of patients. Because of some missing values within individuals when there was not a recording at each time interval, statistical hypothesis testing was done by comparing groups with respect to change from 0 to six months and 0 to 12 months. The statistical software JMP 3.1 was used in the statistical analysis. A p value $<0.05$ was considered to be statistically significant. Two-sided tests were used.

\section{Results}

The Harris hip scores were significantly better in the anabolic group after six and 12 months. The gait speed was faster after six months in the anabolic group and continued to be better after 12 months, as was the Katz index (Table III).

The anabolic group had a decrease of subcutaneous fat according to the measurements of the triceps skinfold, both after six and 12 months (Table IV) and there was a significant difference compared with the control group at six months which had a slight increase of subcutaneous fat. The BMI was unchanged after six months in both groups. After 12 months the BMI was 22.8 in the anabolic group and 23.9 in the control group.

CT showed that the anabolic group did not lose muscle volume in the operated leg during the first 12 months whereas the control group did $(\mathrm{p}<0.01)$. We also found a significant increase in muscle volume in the contralateral leg in the anabolic group (Table IV). Estimations of relative muscle mass showed similar differences between the groups (Table IV).

Table III. Median values and range for clinical assessments and p value between groups

\begin{tabular}{|c|c|c|c|c|c|c|}
\hline & \multicolumn{3}{|l|}{6 months } & \multicolumn{3}{|l|}{12 months } \\
\hline & $\begin{array}{l}\text { Control } \\
\text { group }\end{array}$ & $\begin{array}{l}\text { Anabolic } \\
\text { group }\end{array}$ & p value & $\begin{array}{l}\text { Control } \\
\text { group }\end{array}$ & $\begin{array}{l}\text { Anabolic } \\
\text { group }\end{array}$ & p value \\
\hline Katz index & $6(5$ to 6$)$ & $6(5$ to 6$)$ & 0.7 & $6(2$ to 6$)$ & $6(5$ to 6$)$ & 0.05 \\
\hline Harris hip score & 72 (42 to 91$)$ & $86(59$ to 100$)$ & 0.006 & 79 (48 to 98$)$ & 88.5 (64 to 100$)$ & 0.04 \\
\hline VAS $(\mathrm{mm})$ & $15(0$ to 95$)$ & $3.5(0$ to 69$)$ & 0.09 & $5(0$ to 75$)$ & $6.5(0$ to 41$)$ & 0.8 \\
\hline Gait speed $(\mathrm{s} / 30 \mathrm{~m})$ & $50(20$ to 145$)$ & 34 (20 to 70$)$ & 0.007 & $46(25$ to 250$)$ & $30(20$ to 90$)$ & 0.009 \\
\hline
\end{tabular}


Table IV. Changes in soft tissues after six and 12 months in the anabolic and control groups and the differences between groups

\begin{tabular}{|c|c|c|c|c|c|c|c|c|}
\hline & \multicolumn{2}{|c|}{ On admission } & \multicolumn{3}{|c|}{ Difference at 6 months } & \multicolumn{3}{|c|}{ Difference at 12 months } \\
\hline & $\begin{array}{l}\text { Anabolic } \\
\text { group }\end{array}$ & $\begin{array}{l}\text { Control } \\
\text { group }\end{array}$ & $\begin{array}{l}\text { Anabolic } \\
\text { group }\end{array}$ & $\begin{array}{l}\text { Control } \\
\text { group }\end{array}$ & $\begin{array}{l}\text { p value } \\
\text { between } \\
\text { groups }\end{array}$ & $\begin{array}{l}\text { Anabolic } \\
\text { group }\end{array}$ & $\begin{array}{l}\text { Control } \\
\text { group }\end{array}$ & $\begin{array}{l}\text { p value } \\
\text { between } \\
\text { groups }\end{array}$ \\
\hline \multicolumn{9}{|l|}{ Muscle volume $\left(\mathrm{cm}^{2}\right)$} \\
\hline Operated leg & 53.1 & 51.4 & -0.1 & -7.1 & 0.01 & 3.0 & -6.3 & 0.01 \\
\hline Unoperated leg & 45.9 & 45.9 & 12.6 & 8.6 & 0.004 & 14.1 & 8.1 & 0.002 \\
\hline \multicolumn{9}{|l|}{ Relative muscle mass } \\
\hline Operated leg & 1914 & 1501 & 339 & -25 & 0.03 & 617 & -161 & 0.002 \\
\hline Unoperated leg & 2166 & 1793 & 836 & 573 & 0.02 & 1049 & 434 & 0.0005 \\
\hline Triceps skinfold (mm) & 13.5 & 15.1 & -1.6 & 0.5 & 0.04 & -1.6 & 0.6 & NS \\
\hline BMI $\left(\mathrm{kg} / \mathrm{m}^{2}\right)$ & 23.4 & 23.3 & -1.3 & -1.0 & NS & -1.6 & -0.5 & NS \\
\hline
\end{tabular}

Table V. Changes in bone variables after six and 12 months in the anabolic and control groups

\begin{tabular}{|c|c|c|c|c|c|c|c|c|}
\hline & \multicolumn{2}{|c|}{ On admission } & \multicolumn{3}{|c|}{ Difference at 6 months } & \multicolumn{3}{|c|}{ Difference at 12 months } \\
\hline & $\begin{array}{l}\text { Anabolic } \\
\text { group }\end{array}$ & $\begin{array}{l}\text { Control } \\
\text { group }\end{array}$ & $\begin{array}{l}\text { Anabolic } \\
\text { group }\end{array}$ & $\begin{array}{l}\text { Control } \\
\text { group }\end{array}$ & $\begin{array}{l}\text { p value } \\
\text { between } \\
\text { groups }\end{array}$ & $\begin{array}{l}\text { Anabolic } \\
\text { group }\end{array}$ & $\begin{array}{l}\text { Control } \\
\text { group }\end{array}$ & $\begin{array}{l}p \text { value } \\
\text { between } \\
\text { groups }\end{array}$ \\
\hline \multicolumn{9}{|l|}{ Quantitative CT $\left(\mathrm{g} / \mathrm{cm}^{3}\right)$} \\
\hline Proximal femur & 1133 & 1055 & 13.5 & -21.9 & 0.1 & -3.6 & -41.9 & 0.1 \\
\hline Distal femur & 146 & 142 & -9.6 & -17.9 & 0.08 & -10.4 & -26.6 & 0.007 \\
\hline Proximal tibia & 67 & 65 & -8.8 & -13.4 & 0.04 & -7.8 & -13.4 & 008 \\
\hline \multicolumn{9}{|l|}{ Unoperated leg } \\
\hline Proximal femur & 1103 & 1071 & 28.2 & -2.4 & 0.2 & 8.6 & -6.5 & 0.4 \\
\hline Distal femur & 142 & 140 & -1.0 & -2.5 & 0.6 & 0.9 & -5.3 & 0.2 \\
\hline Proximal tibia & 67 & 65 & 0.8 & -3.6 & 0.03 & 2.2 & -3.2 & 0.01 \\
\hline \multicolumn{9}{|l|}{ DXA $\left(\mathrm{g} / \mathrm{cm}^{2}\right)$} \\
\hline Unoperated hip & & & & & & & & \\
\hline Neck & 0.67 & 0.64 & -0.012 & -0.006 & 0.6 & -0.026 & -0.019 & 0.6 \\
\hline \multicolumn{9}{|l|}{ Quantitative US of the heel (\%) } \\
\hline Stiffness index (operated side) & 57.9 & 54 & 1.4 & -1.6 & 0.06 & 2.4 & 0.3 & 0.09 \\
\hline Stiffness index (unoperated side) & 56.7 & 54.9 & 2.5 & 0.8 & 0.2 & 5.4 & 0.4 & 0.03 \\
\hline
\end{tabular}

There was a preserving effect on BMD in all sites in the anabolic group. In the contralateral tibia there was a decrease in the control group at both six and 12 months. There was less reduction in the anabolic group compared with the control group, at six months in the ipsilateral proximal tibia and at 12 months in the ipsilateral distal femur (Table V). There was no difference between the two groups with regard to changes during the first 12 months in the mid-femoral region. There were no significant absolute differences in bone volume or changes with the passage of time between the two groups. The changes in the bone mineral content followed the BMD findings at all sites.

There was a small rise in plasma calcium levels during treatment for 12 months, from 2.19 to $2.46 \mathrm{mmol} / \mathrm{l}$ for the control group and from 2.20 to $2.48 \mathrm{~mol} / \mathrm{l}$ for the anabolic group. The other laboratory measurements remained within normal levels. There was a significant increase for all bone markers between admission and the follow-up at six months for both groups (Table II), but no significant changes between six and 12 months, the levels of the markers of both bone formation and resorption remaining high compared with those on admission in both groups. There was no significant difference in the levels of bone markers between the two groups and after six and 12 months (Table II).

Three patients had side-effects such as hoarseness or increased facial hair from the treatment.

\section{Discussion}

Many functionally independent people who are living at home before fracture of the hip require placement in a nursing home and do not regain their previous level of function. ${ }^{6}$ One important predictor for discharge after a hip fracture is the ability to walk after operation ${ }^{47}$ and it is therefore important to evaluate whether more active postoperative treatment can improve the long-term outcome. A variety of functional tests is available which correlate well with lean body mass and muscle mass. ${ }^{48}$ The anabolic group had better function and walking ability after six and 12 months compared with the control group. Few studies have evaluated the use of anabolic steroids on function after a hip fracture. A pilot study of 19 patients followed for four weeks showed, contrary to our findings, no detectable benefits for treatment with nandrolone decanoate, ${ }^{49}$ but the period of study was short. A double-blind study showed 
better mobility and less pain in patients with vertebral fractures after treatment with this drug compared with alphacalcidol. 50

It is not clear whether treatment with anabolic steroids increases muscle volume and strength in all young healthy athletes, but it is effective in those who have trained to the point at which they are in a catabolic state. ${ }^{51}$ We used a much smaller dose than that used by athletes to see if it could preserve lean body mass in elderly patients with fractures of the hip who often are in a catabolic state after surgery. We found a change in body composition, with an increase in muscle volume in the contralateral leg and a preserving effect on the muscle volume in the ipsilateral leg in the anabolic group after six and 12 months. There was a simultaneous decrease in subcutaneous fat in the anabolic group. Similar findings have been reported in postmenopausal osteoporotic women, with an increase in lean body mass and a corresponding decrease in fat mass measured by DXA after treatment with a dose of nandrolone which was twice that used in our study. ${ }^{52}$ Recently, Villareal et $\mathrm{al}^{26}$ described similar treatment with dihydroepiandrosterone in elderly patients. Apart from an increase in BMD there was an altered body composition with a reversal of age-related changes, a net gain in lean body mass and a decrease in fat mass. These results support our findings which show a reversal of the catabolic state which normally follows a fracture of the hip involving a loss of BMD, a decrease in lean body mass and an increase in fat mass. $1,10,18$

In order to establish whether the increase in the muscle volume merely reflected fluid retention, ${ }^{53}$ we also measured the attenuation value and relative muscle mass and found the same differences between the two groups, indicating an increase of muscle tissue rather than oedema. Whether this increase in muscle volume is accompanied by an increase in strength has not been proven.

It is uncertain whether the preserving effect on the volume of thigh muscle was an effect of the anabolic steroids alone since the administration of vitamin D to patients with established deficiency of vitamin D restores muscle strength. ${ }^{54}$ It has been suggested that the weakness associated with ageing is partly due to inadequate levels of vitamin D. No relationship between vitamin D and muscle strength was found in healthy elderly women, ${ }^{55}$ and this was confirmed in a randomised, double-blind study in which vitamin D was given to mobile healthy elderly subjects with relatively normal vitamin D status. ${ }^{56}$

Vitamin D and calcium were found to have a protective effect against fractures of the hip in elderly patients in nursing homes, ${ }^{57}$ but lower doses of vitamin $\mathrm{D}$ did not reduce the incidence of fractures in independent patients. ${ }^{58}$ The reason for the reduced incidence in the residents of nursing-homes is unclear since treatment with vitamin D does not generate the expected increase in BMD, but merely reduces bone loss. ${ }^{59}$ It may be that the positive effect of vitamin $\mathrm{D}$ on muscle reduces the incidence of injuries caused by falls. ${ }^{60}$ The prevalence of deficiency of vitamin D and the low calcium absorption which increases with age, has geographical, racial and seasonal differences. $^{27,29,61}$ Probably most important, however, is the difference between mobile and institutionalised patients. ${ }^{29,62-64}$ The variable effects of supplementation with vitamin $\mathrm{D}$ on bone and muscles may be related to the selection of patients in the different studies.

Most studies use supplements with vitamin D while we used alphacalcidol, which is an active metabolite of vitamin D. Currently, it is only recommended for patients with renal failure since earlier studies have shown that higher doses of metabolites of vitamin D may cause hypercalcaemia. Mild hypercalcaemia occurred in only two patients receiving alphacalcidol in our study. One of these was later shown to have primary hyperparathyroidism which contributed to the hypercalcaemia. Studies on the effect of alphacalcidol on BMD have yielded conflicting results, but have shown a decrease in spinal bone loss and a reduction of the incidence of vertebral fractures in elderly women. ${ }^{65-66}$

We found that the anabolic group, treated with a lower dose of nandrolone decanoate than in earlier studies, lost less BMD than the control group, particularly in the distal femur and proximal tibia which are areas with mostly trabecular bone. There were also positive effects on BMD in the femoral diaphysis, which is mostly cortical bone, on the injured side after both six and 12 months. Bone remodelling is a surface-based process and the metabolic activity of cancellous bone is tenfold greater than that at cortical sites. $^{67}$ It is thus not surprising that we found preserving effects on BMD mainly in the sites with trabecular bone.

An early study reported an increase in BMC of the distal forearm after one year which was not acompanied by an increase in BMD, and the authors suggested that nandrolone decanoate may act by increasing bone size. ${ }^{68}$ This was not confirmed by us or others. ${ }^{69}$ Need et $\mathrm{al}^{21}$ found an increase in BMC in the forearm when giving $50 \mathrm{mg}$ of nandrolone decanoate every third week for one year, compared with a decrease in a control group, but they had a high incidence of hoarseness while we had a low incidence using half the dose. Another study matched pairs of postmenopausal women with osteoporosis to hormone replacement therapy with or without this drug. There was a significant increase in BMC and BMD of the lumbar spine in the third year in the group receiving the steroid. This effect was still apparent 12 months after stopping treatment. $^{70}$ Long-lasting beneficial effects have also been reported by others. ${ }^{71}$

Although several studies have described the changes in BMD after treatment with nandrolone decanoate, these results are difficult to interpret and compare because of the use of different methods of measuring densitometry at different sites. Our results suggest that it may be possible to preserve BMD with a dose which is not associated with significant side-effects. Whether our findings of a beneficial effect on trabecular bone were due to an increased formation or mineralisation or by reduced resorption of bone is 
unclear. Both formation and resorption markers of bone were increased after six months and remained high after 12 months, indicating an increased turnover of bone after a fracture of the hip, as we have previously reported. ${ }^{72}$ The high bone turnover could be associated with post-traumatic osteopenia and fracture healing. There was no significant difference in the levels of bone markers between the two groups despite the anabolic treatment and the differences noted in BMD. Minor differences in the levels of bone markers may not be detectable because of the already increased bone turnover induced by the trauma.

This study suggests that a low dose of nandrolone decanoate in combination with a low dose of alphacalcidol and calcium has a positive effect on body composition, BMD and the clinical function in elderly women after fracture of the hip.

This study was supported by grants from the Swedish Society for Medical Research and Trygg-Hansa.

No benefits in any form have been received or will be received from a commercial party related directly or indirectly to the subject of this article.

\section{References}

1. Hedström M, Sääf $\mathbf{M}$, Dalén $\mathbf{N}$. Low IGF-I levels in hip fracture patients: a comparison of 20 coxarthrotic and 23 hip fracture patients. Acta Orthop Scand 1999;70:145-8.

2. Patterson B, Cornell C, Carbone B, Levine B, Chapman D. Protein depletion and metabolic stress in elderly patients who have a fracture of the hip. J Bone Joint Surg [Am] 1992;74-A:251-60.

3. Hillier S, Cooper C, Kellingray S, et al. Fluoride in drinking water and risk of hip fracture in the UK: a case control study. Lancet 2000;22:265-9.

4. Thibaud D, Burckhardt P, Costanza M, et al. Importance of albumin, 25(OH)-vitamin D and IGFBP-3 as risk factors in elderly women and men with hip fracture. Osteoporosis Int 1997;7:457-62.

5. Delmi M, Rapin CH, Bengoa JM, et al. Dietary supplementation in elderly patients with fractured neck of the femur. Lancet 1990;335:1013-6.

6. Sernbo I, Johnell O. Consequences of a hip fracture: a prospective study over 1 year. Osteoporos Int 1993;3:148-53.

7. Berglund-Rödén M, Swierstra BA, Wingstrand H, Thorngren KG. Prospective comparison of hip fracture treatment: 856 cases followed for 4 months in the Netherlands and Sweden. Acta Orthop Scand 1995;65:287-95.

8. Holmberg S, Conradi P, Kalén R, Thorngren KG. Mortality after cervical hip fracture: 3002 patients followed for 6 years. Acta Orthop Scand 1986;57:8-11.

9. Hedström M,Gröndal L, Örtquist Å, Dalén N, Ahl T. Serum albumin and deep infection in femoral neck fractures: a study of 437 cases followed for one year. Int Orthop 1998;22:182-4.

10. Fox KM, Magaziner J, Hawkes WG, et al. Loss of bone density and lean body mass after hip fracture. Osteoporosis Int 2000;11:31-5.

11. Nevitt MC, Cummings SR, Hudes ES. Risk factors for injurious falls: a prospective study. J Gerontol 1991;46:M164-70.

12. Nevitt MC, Cummings SR. Type of fall and risk of hip and wrist fractures: the study of osteoporotic fractures. J Am Geriatr Soc 1993;41:1226-34.

13. Skelton DA, Greig CA, Davies JM, Young A. Strength, power and related functional ability of healthy people aged 65-89 years. Age Ageing 1994;23:371-7.

14. Kay SP, Moreland JR, Schmitter E. Nutritional status and wound healing in lower extremity amputation. Clin Orthop 1987;217:253-6.

15. Puskarich CL, Nelson CL, Nusbickel FR, Stroope HF. The use of two nutritional indicators in identifying long bone fracture patients who do and do not develop infections. $J$ Orthop Res 1990;8:799-803
16. Berger JR, Pall $\mathbf{L}$, Hall CD, et al. Oxandrolone in AIDS-wasting myopathy. AIDS 1996;10:1657-62.

17. Ferreira IM, Verreschi IT, Nery LE, et al. The influence of 6 months of oral anabolic steroids on body mass and respiratory muscles in undernourished COPD patients. Chest 1998;114:19-28.

18. Karlsson M, Nilsson JÅ, Sernbo I, et al. Changes of bone mineral mass and soft tissue composition after hip fracture. Bone 1996; 18:19-22.

19. Neander G, Adolphson $P$, Hedström $M$, et al. Decrease in bone mineral density and muscle mass after femoral neck fracture: a quantitative computed tomography study on 25 patients. Acta Orthop Scand 1997;68:451-55.

20. Cummings SR, Black DM, Nevitt MC, et al. Bone density at various sites for prediction of hip fractures. Lancet 1993;341:72-5.

21. Need AG, Morris HA, Hartly TF, Horowitz M, Nordin BE. Effects of nandrolone decanoate on forearm mineral density and calcium metabolism in osteoporotic postmenopausal women. Calcif Tissue Int 1987;41:7-10.

22. Flicker L, Hopper JL, Larkins RG, et al. Nandrolone decanoate and intranasal calcitonin as therapy in established osteoporosis. Osteoporosis Int 1997;7:29-35.

23. Hamburger C. Normal urinary excretion of neutral 17-ketosteroids with special reference to age and sex variations. Acta Endocrinol 1948;1:19-37.

24. Laughlin GA, Barrett-Connor E. Sexual dimorphism in the influence of advanced ageing on adrenal hormone levels: the Rancho Bernardo Study. J Clin Endocrinol Metab 2000;85:3561-8.

25. Zofkova I, Bahbouh R, Hill M. The pathophysiological implications of circulating androgens on bone mineral density in a normal female population. Steroids 2000;65:857-61.

26. Villareal DT, Holloszy JO, Kohrt WM. Effects of DHEA replacement on bone mineral density and body composition in elderly women and men. Clin Endocrinol (OXF) 2000;53:561-8.

27. Webb AR, Pilbeam C, Hanafin N, Holick MF. An evaluation of the relative contributions of exposure to sunlight and of diet to the circulating concentrations of 25-hydroxyvitamin D in an elderly nursing home population in Boston. Am J Clin Nutr 1990;51:1075-81.

28. Fuleihan GE, Deeb M. Hypovitaminosis D in a sunny country. $N$ Engl J Med 1999;340:1840-1.

29. McKenna MJ. Differences in vitamin D status between countries in young adults and the elderly. Am J Med 1992;93:69-77.

30. Holick MF. Environmental factors that influence the cutanous production of vitamin D. Am J Clin Nutr 1995;61(3 Suppl):638-45.

31. Baker MR, McDonnell H, Peacock M, Nordin BE. Plasma 25-hydroxy vitamin D concentrations in patients with fractures of the femoral neck. BMJ 1979;1:589.

32. Lips P, Netelenbos JC, Jongen MJM, et al. Histomorphometric profile and vitamin D status in patients with femoral neck fracture. Metab Bone Dis Relat Res 1982;4:85-93.

33. Boonen S, Aerssens J, Dequeker J. Age-related endocrine deficiencies and fractures of the proximal femur: II implications of vitamin D deficiency in the elderly. J Endocrinol 1996;149:13-7.

34. LeBoff M, Kohlmeier L, Hurwitz S, et al. Occult vitamin D deficiency in postmenopausal US women with acute hip fracture. JAMA 1999;281:1505-11.

35. Lamberg-Allard C. Vitamin D intake, sun light exposure and 25-hydroxyvitamin D levels in the elderly during one year. Ann Nutr Metab 1984;28131-7.

36. Harris WH. Traumatic arthritis of the hip after dislocation and acetabular fracture: treatment by Mold arthroplasty. J Bone Joint Surg [Am] 1969;51-A:737-55.

37. Scott J, Huskisson EC. Graphic presentation of pain. Pain 1976;2:175-84.

38. Olsson E, Goldie I, Wykman A. Total hip replacement: a comparison between cemented (Charnley) and non-cemented (HP Garches) fixation by clinical assessment and objective gait analysis. Scand J Rehabil Med 1986;18:107-16.

39. Katz S, Ford AB, Moskowitz RW, Jackson BA, Jaffe MW. Studies of illness in the aged: the index of ADL: a standardized measure of biological and psychosocial function. JAMA 1963;185:914-9.

40. Lees B, Stevenson JC. An evaluation of dual-energy X-ray absorptiometry and comparison with dual-photon absorptiometry. Osteoporosis Int 1992;2:146-52. 
41. Hansen M, Hassager C, Overgaard K, Marslew U, Riis B, Christiansen C. Dual-energy X-ray absorptiometry: a precise method of measuring bone mineral density in spine. J Nucl Med 1990;31:1156-62.

42. Neander G, Adolphson P, von Sivers K, Dahlborn M, Dalén N. Bone and muscle mass after femoral neck fracture: a controlled quantiative computed tomography study of osteosynthesis versus primary total hip arthroplasty. Arch Orthop Trauma Surg 1997;116:470-4.

43. Steiger P, Block JE, Steiger $\mathbf{S}$, et al. Spinal bone mineral density measured with quantitative CT: effect of region of interest, vertebral level and technique. Radiology 1990;175:537-43.

44. Karantanas A, Kalef-Ezra J, Glaros D. Quantitative computed tomography for bone mineral measurement: technical aspects, dosimetry, normal data and clinical application. $\mathrm{Br} \quad J$ Radiol 1991;64:298-304.

45. Truscott JG, Simpson M, Stewart S, et al. Bone ultrasonic attenuation in women: reproducibility, normal variation and comparison with photon absorptiometry. Clin Phys Physiol Meas 1992;13:29-36.

46. Symreng T. Arm anthropometry in a large reference population and in surgical patients. Clin Nutr 1982;1:211-9.

47. Thorngren KG, Ceder L, Svensson K. Predicting results of rehabilitation after hip fracture: a ten-year follow-up study. Clin Orthop 1993;287:76-81

48. Vellas B, Albarede JL, Garry PJ. Disease and ageing: pattern of morbidity with age; relationship between ageing and age-associated diseases. Am J Clin Nutr 1992;55(6 Suppl):1225-30.

49. Sloan JP, Wing P, Dian L, Meneilly GS. A pilot study of anabolic steroids in elderly patients with hip fractures. J Am Geriatr Soc 1992;40:1105-11

50. Haupt H, Rovere GD. Anabolic steroids: a review of the literature Am J Sports Med 1984;12:469-84.

51. Lyritis G, Androulakis C, Magiasis B, Charalambaki Z, Tsakalakos N. Effect of nandrolone decanoate and 1-alpha-hydroxy-calciferol on patients with vertebral osteoporotic collapse: a double-blind clinical trial. Bone Miner 1994;27:209-17.

52. Hassager C, Pödenphant $\mathbf{J}$, Riis BJ, et al. Changes in soft tissue body composition and plasma lipid metabolism during nandrolone decanoate therapy in postmenopausal osteoporotic women. Metabolism 1989;38:238-42.

53. Hervey GR, Knibbs AV, Burkinshaw L, et al. Effects of methandienone on the performance and body composition of men undergoing athletic training. Clin Science (Lond) 1981;60:457-61.

54. Glerup H, Mikkelsen $K$, Poulsen $\mathbf{L}$, et al. Hypovitaminosis D myopathy without biochemical signs of osteomalacic bone involvement. Calcif Tissue Int 2000;66:419-24.

55. Boonen S, Lysens R, Verbeke $\mathbf{G}$, et al. Relationship between ageassociated endocrine deficiencies and muscle function in elderly women: a cross-sectional study. Age Ageing 1998;27:449-54.

56. Grady D, Halloran B, Cummings S, et al. 1,25-Dihydroxyvitamin D, and muscle strength in the elderly: a randomised controlled trial. Clin Endocrinol Metab 1991;73:1111-7.
57. Chapuy MC, Arlot ME, Delmas PD, Meunier PJ. Effect of calcium and cholecalciferol treatment for three years on hip fractures in elderly women. BMJ 1994;308:1081-2.

58. Lips P, Graafmans WC, Ooms ME, Bezemer PD, Bouter LM. Vitamin D supplementation and fracture incidence in elderly persons: a randomized placebo-controlled clinical trial. Ann Intern Med 1996;124:400-6.

59. Dawson-Hughes B, Dallal GE, Krall EA, et al. A controlled trial of the effect of calcium supplementation on bone density in postmenopausal women. N Engl J Med 1990;323:878-83.

60. Pfeifer M, Begerow B, Minne HW, et al. Effects of a short-term vitamin $\mathrm{D}$ and calcium supplementation on body sway and secondary hyperparathyroidism in elderly women. $J$ Bone Miner Res 2000;15:1113-8.

61. Harris SS, Soteriades E, Coolidge JA, Mudgal S, Dawson-Hughes B. Vitamin D insufficiency and hyperparathyroidism in a low income, multiracial, elderly population. J Clin Endocrinol Metab 2000;85:4125-30.

62. Sem SW, Sjoen RJ, Trygg K, Pedersen JI. Vitamin D status of two groups of elderly in Oslo: living in old people's homes and living in own homes. Compr Gerontol (A) 1987;1:126-30.

63. Komar L, Nieves J, Cosman F, et al. Calcium homeostasis of an elderly population upon admission to a nursing home. J Am Geriatr Soc 1993;41:1057-64.

64. Corless D, Gupta SP, Sattar DA, Switala S, Boucher BJ. Vitamin D status of residents of an old people's home and long-stay patients. Gerontology 1979;25:350-5.

65. Orimo H, Shiraki M, Hayashi Y, et al. Effects of 1alpha hydroxyvitamin D3 on lumbar bone mineral density and vertebral fractures in patients with postmenopausal osteoporosis. Calcif Tissue Int 1994;54:370-6

66. Francis RM, Boyle IT, Moniz C, et al. A comparison of the effects of alfacalcidol treatment and vitamin D2 supplementation on calcium absorption in elderly women with vertebral fractures. Osteoporosis Int 1996;6:284-90.

67. Kanis JA. The use of calcium in the management of osteoporosis. Bone 1999;24:279-90.

68. Johansen JS, Hassager C, Pödenphant J, et al. Treatment of postmenopausal osteoporosis: is the anabolic steroid nandrolone decanoate a candidate? Bone Miner 1989;6:77-86.

69. Need AG, Horowitz M, Walker CJ, et al. Cross-over study of fatcorrected forearm mineral content during nandrolone decanoate therapy for osteoporosis. Bone 1989;10:3-6.

70. Erdtsieck RJ, Pols HAP, van Kuijk C, et al. Course of bone mass during and after hormonal replacement therapy with and without addition of nandrolone decanoate. J Bone Miner Res 1994;9:277-83.

71. Geusen $\mathbf{P}$, Dequeker J, Verstraeten A, Nijs J, Van Holsbeeck $M$. Bone mineral content, cortical thickness and fracture rate in osteoporotic women after withdrawal of treatment with nandrolone decanoate, 1-alpha hydroxy-vitamin $\mathrm{D}_{3}$ or intermittent calcium infusions. Maturitas 1986;8:281-9.

72. Hedström M, Sjöberg K, Svensson J, Brosjö E, Dalén N. Changes in biochemical bone markers of bone metabolism and BMD during the first year after a hip fracture. Acta Orthop Scand 2001;72:248-51. 